\title{
Gambaran Perilaku Menggosok Gigi pada Siswa SD Kelas Satu dengan Karies Gigi di Wilayah Kerja Puskesmas Rendang Karangasem Bali Oktober 2014
}

\author{
I Dewa Gede Bracika Damma Prasada \\ Program Studi Pendidikan Dokter, Fakultas Kedokteran Universitas Udayana
}

Diterima: 3 Maret 2016. Disetujui: 31 Maret 2016. Diterbitkan: Juni 2016

\begin{abstract}
ABSTRAK
Latar Belakang: Prevalensi karies pada usia lebih dari 12 tahun di Indonesia mencapai 46,5\%. Dapat dilihat dari prevalensi tersebut mayoritas siswa sekolah di Indonesia mengalami karies. Menurut data RISKESDAS 2007 dikatakan bahwa 91,1\% penduduk Indonesia usia 10 tahun keatas melakukan sikat gigi setiap hari, namun hanya 7,3\% yang telah menyikat gigi dua kali di waktu yang benar yaitu pada pagi hari setelah sarapan dan malam sebelum tidur. Di Puskesmas Kecamatan Rendang, karies gigi termasuk dalam 10 besar penyakit terbanyak pada tahun 2013. Oleh karena itu, penelitian ini ditujukan untuk mengetahui gambaran perilaku menggosok gigi terhadap kejadian karies gigi karena menggosok gigi merupakan perilaku yang sangat penting dalam pencegahan karies gigi.

Metodologi: Penelitian ini mempergunakan rancangan penelitian deskriptif dengan pendekatan cross sectional. Sampel penelitiannya adalah siswa Sekolah Dasar kelas satu yang menderita karies gigi di SDN 2 dan SDN 4 Rendang dengan besar sampel yang digunakan adalah 39. Teknik pengambilan sampel adalah dengan menggunakan cara Accidental sampling, yaitu dengan mengambil sampel yang hadir pada waktu penelitian.

Hasil dan Kesimpulan: Hasil penelitian didapatkan 31\% responden tidak menggosok gigi setiap hari, 33\% responden tidak menggunakan sikat gigi sendiri, $10 \%$ responden tidak menggunakan pasta gigi, dan 33\% menggosok gigi hanya 1 kali dalam sehari. Hanya 3,7\% yang didapatkan menggosok gigi benar pagi yaitu setelah sarapan dan menggosok malam benar yaitu sebelum tidur. Tiada responden yang didapatkan menggosok gigi menggunakan metode menggosok gigi yang benar.
\end{abstract}

Kata kunci: Karies, Menggosok gigi, Perilaku, Prevalensi

\section{DESCRIPTION OF TOOTHBRUSHING HABIT OF PRIMARY SCHOOL CLASS ONE WITH DENTAL CARIES IN RENDANG PUBLIC HEALTH KARANGASEM BALI OCTOBER 2014}

\section{ABSTRACT}

Background: The prevalence of dental caries in those with age more than 12 years old in Indonesia reaches $46,5 \%$. From the prevalence we could see that the majority of students in Indonesia have dental caries. According to RISKESDAS 2007 data, it is said that 91, 1\% of Indonesian citizen with age more than 10 years old does brush their teeth every day, but only 7, 3\% of them that brush their teeth 2 times a day at the right time which is in the morning after breakfast and at night before bedtime. At Rendang Public Health, dental caries is one of the top 10 diseases of the year 2013. Because of that, this study is done to know the description of tooth brushing habit towards incidence of dental caries because tooth brushing is an important habit for dental caries prevention.

Methodology: This study is a descriptive survey study with cross sectional approach. Research sample are Primary School class one students from SDN 2 and SDN 4 Rendang with sample size used are 39. Data 
sampling technique which is used for this study was Accidental sampling where whatever sample who present on that day was taken.

Results and Discussion : The result of the study shows that 31\% of respondents doesn't brush their teeth every day, 33\% of respondents doesn't use their own toothbrush, $10 \%$ of the respondents doesn't use toothpaste, and $33 \%$ brush their teeth only once in a day. Only 3, 7\% of the respondents brush their teeth at the right time which is brushing teeth in the morning after breakfast and at night before bedtime. There is not a single respondent that brush their teeth using the correct tooth brushing method.

Keywords : Caries, Tooth brushing, Habit, Prevalence

\section{PENDAHULUAN}

Kesehatan gigi dan mulut masyarakat di Indonesia masih merupakan hal yang penting untuk mendapatkan perhatian khusus dari tenaga kesehatan, baik dokter maupun perawat gigi. ${ }^{1}$ Walaupun terjadi peningkatan prevalensi terhadap kesehatan gigi dan mulut, karies gigi pada anak tetap merupakan masalah klinik yang signifikan. Karies gigi merupakan penyakit infeksi dan merupakan suatu proses demineralisasi yang progresif pada jaringan keras permukaan mahkota dan akar gigi yang dapat dicegah. $^{2}$

Di Indonesia penyakit gigi dan mulut yang bersumber dari karies gigi menjadi urutan tertinggi yaitu sebesar 45,68\% dan termasuk dalam 10 besar penyakit yang diderita oleh masyarakat. Berdasarkan kelompok usia, golongan usia muda lebih banyak menderita karies dibandingkan dengan usia 45 tahun keatas. Menurut data Depkes 2005, pada usia 10 - 24 tahun sekitar 66,8 - 69,5\% merupakan penderita karies gigi, usia lebih dari 45 tahun mencapai 53,3\% dan usia lebih dari 65 tahun sebesar 43,8\%. Menurut RISKESDAS 2007, prevalensi karies pada usia lebih dari 12 tahun di Indonesia mencapai 46,5\%. Dapat dilihat dari prevalensi tersebut mayoritas siswa sekolah di Indonesia mengalami karies. Menurut data RISKESDAS 2007 dikatakan bahwa 91,1\% penduduk Indonesia usia 10 tahun keatas melakukan sikat gigi setiap hari, namun hanya $7,3 \%$ yang telah menyikat gigi dua kali di waktu yang benar yaitu pada pagi hari setelah sarapan dan malam sebelum tidur. Angka yang didapatkan hampir sama terjadi di Provinsi Bali dimana $86,2 \%$ penduduk Bali menyikat giginya setiap hari namun hanya $10,9 \%$ yang menyikat gigi dengan waktu dan metode yang benar. $^{3}$

Di Puskesmas Kecamatan Rendang, karies gigi termasuk dalam 10 besar penyakit terbanyak pada tahun 2013, Karies gigi menempati urutan ke-4 setelah penyakit Hipertensi primer yaitu sebesar 7,35\% dan menempati urutan ke-5 pada tahun 2012. Berdasarkan data dari Pelayanan Kesehatan pada siswa SD dan setingkat masalah kesehatan anak usia sekolah semakin komplek dimana masalah kesehatan yang sering salah satu nya adalah karies gigi. Penderita karies gigi pada tahun 2012 menurut data UKGS adalah 3,7\% sedangkan pada tahun 2013 sudah mengalami penurunan menjadi 2,3\%. Dari data penjaringan tahun 2013, persentase tertinggi karies gigi terdapat pada 7 Sekolah Dasar dimana $100 \%$ siswa kelas satu mengalami karies gigi yaitu SDN 2 Pesaban, SDN 2 \& 4 Rendang, SDN 6 Menanga, SDN 1 \& 5 Pempatan, SDN 1 \& 3 Besakih, sedangkan persentase terendah yaitu $15 \%$ terdapat pada SDN 1 Nongan dan SDN 5 Menanga. Persentase karies gigi pada siswa SD kelas 1 adalah $79 \%$.

Dampak dari karies yang berat dapat mempengaruhi kualitas hidup anak-anak yaitu pengalaman akan nyeri. Rasa tidak nyaman saat makan, gangguan tidur, juga risiko yang lebih tinggi untuk dirawat di rumah sakit sehingga menyebabkan biaya pengobatan yang lebih tinggi, dan kehilangan harihari di sekolah akibat penurunan kemampuan mereka untuk belajar. Anak - anak yang mengalami nyeri gigi tidak akan menjawab tes sebaik anak-anak yang tidak diganggu oleh nyeri gigi. Karies gigi juga mempengaruhi nutrisi, pertumbuhan dan pertambahan berat badan anak. ${ }^{4}$ 
Upaya yang telah dilakukan oleh Puskesmas Rendang untuk menurunkan kasus karies pada siswa SD yaitu Pelayanan asuhan pada anak sekolah yang biasa dilakukan 1 tahun sekali antara bulan Agustus September yang meliputi skrining pemeriksaan gigi dan penyuluhan sikat gigi masal di SD. Upaya ini sudah mencapai target yang ditentukan yaitu $80 \%$ dan berjalan sesuai dengan jadwal yang telah ditentukan.

Berdasarkan teori Blum, status kesehatan seseorang atau masyarakat dipengaruhi oleh empat faktor penting yaitu genetik, lingkungan (fisik maupun sosial budaya), perilaku dan pelayanan kesehatan. Dari keempat faktor tersebut, lingkungan dan perilaku memegang peranan penting dalam mempengaruhi status kesehatan khususnya karies gigi. Perilaku yang dapat meliputi perilaku menggosok gigi dan makan - makanan manis. ${ }^{2}$

Menurut survey yang telah dilakukan di salah satu Sekolah Dasar wilayah kerja Puskesmas Rendang, 9 dari 10 siswa SD kelas 1 yang mengalami karies gigi menggosok giginya setiap hari namun hanya 6 siswa yang melakukannya 2 kali sehari dan hanya 4 dari 10 yang menggosok gigi sebelum tidur. Metode menggosok gigi yang benar dilakukan oleh 5 dari 10 siswa yang mengalami karies gigi. Berdasarkan survey juga ditemukan 6 diantaranya suka memakan makanan manis dan 7 dari mereka suka mengkonsumsi sayuran dan buah.

Berdasarkan hal - hal tersebut, penelitian ini ditujukan untuk mengetahui gambaran perilaku menggosok gigi terhadap siswa Sekolah Dasar kelas satu yang menderita karies gigi di wilayah kerja Puskesmas Rendang.

\section{METODE PENELITIAN}

\section{Rancangan Penelitian}

Penelitian ini mempergunakan rancangan penelitian deskriptif dengan pendekatan cross sectional.

\section{Tempat dan Waktu Penelitian}

Penelitian dilakukan Sekolah Dasar yang terdapat di wilayah kerja Puskesmas Rendang pada Oktober 2014.

\section{Populasi \& Sampel Penelitian}

1. Populasi

Populasi penelitian ini adalah semua siswa Sekolah Dasar kelas satu di wilayah kerja Puskesmas Rendang.

\section{Sampel}

Sampel dalam penelitian ini adalah siswa Sekolah Dasar kelas satu yang menderita karies gigi di wilayah kerja Puskesmas. Dengan persyaratan sebagai berikut :

a. Kriteria Inklusi :

i. Siswa sekolah dasar kelas 1 di wilayah kerja Puskesmas Rendang yang hadir pada saat pengumpulan dan bersedia diperiksa

ii. Siswa sekolah dasar kelas 1 di wilayah kerja Puskesmas Rendang yang kooperatif dalam mengikuti proses wawancara dan observasi

iii. Siswa sekolah dasar kelas 1 di wilayah kerja Puskesmas Rendang yang memiliki minimal satu gigi yang terkena karies.

b. Kriteria Eksklusi :

Siswa SDN 2 \& SDN 4 Rendang yang tidak memiliki gigi sehingga tidak memungkinkan untuk menggosok gigi.

Besar Sampel, Cara Perhitungan dan Cara Pengambilan Sampel

1. Besar Sampel

Besar sampel yang diteliti ditentukan berdasarkan rumus dibawah ini:

$$
\begin{gathered}
n=\frac{z_{\alpha}{ }^{2}(p q)}{d^{2}} \\
n=\frac{1,96^{2}(0,4 \times 0,6)}{0,15^{2}} \\
n=41
\end{gathered}
$$

Keterangan:

$n$ : besar sampel

$z_{\alpha}$ : sama dengan 1,96 pada confidence interval $95 \%$

$p$ : proporsi minimal populasi target

$q: 1-p$

$d$ : ketepatan absolut yang dipakai (ditetapkan oleh peneliti $=15 \%$ ) 
Karena jumlah populasi siswa sekolah dasar kelas 1 di wilayah kerja Puskesmas Rendang kurang dari 10.000 orang.

Maka sampel untuk penelitian ini dikoreksi dengan cara sebagai berikut:

$$
\mathrm{nk}=\frac{\mathrm{n}}{1+\mathrm{n} / \mathrm{N}}=\frac{41}{1+41 / 642}=39
$$

Berdasarkan perhitungan diatas, didapatkan jumlah sampel minimal dalam penelitian ini adalah sebanyak 39 orang.

\section{Cara Pengambilan Sampel}

Sekolah dasar diambil dengan menggunakan metode purposive sehingga diambil SDN 2 \& SDN 4 Rendang. Hal ini dikarenakan persentase karies gigi pada siswa kelas 1 di SDN 2 \& SDN 4 Rendang termasuk dalam salah satu yang tertinggi dari 33 Sekolah Dasar yang terdapat di Wilayah Kerja Puskesmas Rendang pada tahun 2013 dan mudah dijangkau lokasinya. Untuk sampel diambil dengan menggunakan metode Accidental sampling. Siswa kelas satu di SDN 2 dan SDN 4 Rendang dipanggil namanya berdasarkan absensi kelas untuk dilakukan pemeriksaan gigi terlebih dahulu oleh perawat gigi, siswa yang menderita karies gigi menurut pemeriksaan dari perawat gigi tersebut dilanjutkan dengan wawancara oleh peneliti yang dilakukan di bangku masingmasing.

\section{Variabel Penelitian}

Variabel penelitian ini antara lain, karies gigi, jenis kelamin, umur, metode menggosok gigi, frekuensi menggosok gigi, durasi menggosok gigi, waktu menggosok gigi, penggunaan pasta gigi saat menggosok gigi, dan jenis sikat gigi yang digunakan.

\section{Definisi Operasional Variabel Penelitian}

1. Karies gigi adalah lubang pada gigi minimal 1 gigi, diperoleh melalui pemeriksaan yang dilakukan oleh perawat gigi dengan menggunakan sonde dan kaca mulut.
2. Jenis Kelamin adalah jenis kelamin sampel yang dilihat dari daftar absensi kelas

3. Umur adalah umur sampel yang dilihat dari daftar absensi kelas

4. Metode menggosok gigi adalah bagaimana sampel melakukan gosok gigi dilihat dari arah dan gerakan dari menggosok gigi, yang diperoleh melalui observasi

5. Frekuensi menggosok gigi adalah berapa kali dalam sehari sampel melakukan gosok gigi, diperoleh melalui wawancara

6. Durasi menggosok gigi adalah lama waktu yang dibutuhkan sampel untuk satu kali meggosok gigi, diperoleh melalui observasi

7. Waktu meggosok gigi adalah waktu saat sampel melakukan gosok gigi misalnya sebelum sarapan, saat mandi pagi, setelah sarapan, saat mandi sore, setelah makan malam, atau sebelum tidur malam hari, diperoleh melalui observasi.

8. Penggunaan pasta gigi adalah setiap kali menggosok gigi apakah sampel selalu menggunakan pasta gigi atau tidak, diperoleh melalui wawancara.

9. Pemilihan sikat gigi adalah sikat gigi yang digunakan sehari - hari saat melakukan gosok gigi dilihat dari ukuran dan bulu sikatnya, diperoleh melalui observasi.

\section{Prosedur Pengumpulan Data}

1. Responden

Responden penelitian yaitu siswa kelas 1 di SDN 2 \& SDN 4 Rendang yang menderita karies gigi selanjutnya ditetapkan sebagai responden.

\section{Instrumen Pengumpulan Data}

Instrumen penelitian yang digunakan pada penelitian ini adalah kuisioner yang berisikan pertanyaanpertanyaan untuk mengetahui gambaran perilaku menggosok gigi pada siswa kelas satu di SDN 2 \& SDN 4 Rendang yang menderita karies gigi. Untuk mencari siswa SD kelas 1 dengan karies gigi, dibantu oleh seorang perawat gigi yang akan memeriksa siswa terlebih dahulu. Pemeriksaan dilakukan dengan kaca mulut dan sonde, kemudian mencatat bagian gigi yang berlubang di lembar pemeriksaan. 


\section{Cara Pengumpulan Data}

Metode yang digunakan untuk mengumpulkan data pada penelitian ini adalah wawancara kuisioner pada siswa kelas 1 di SDN 2 \& SDN 4 Rendang yang menderita karies gigi. Selain itu, dilakukan observasi terhadap jenis sikat gigi, metode, dan durasi menggosok gigi terhadap responden.

\section{Sistem Skoring}

Pada item dalam kuisioner dan di lembar observasi yang merupakan bagian dari perilaku menggosok gigi yaitu rutinitas, frekuensi, durasi,waktu, metode, penggunaan pasta gigi dan jenis sikat gigi yang dilakukan secara benar menggosok gigi diberikan nilai 1 dan apabila salah diberikan nilai 0 . Skor ini kemudian akan dijumlahkan untuk mengetahui total skor. Item- item lain di kuisioner tidak diberikan skor.

\section{Analisa Data}

1. Data entry dilakukan dengan menggunakan software SPSS versi 16.0

dan dilakukan cleaning data sesudahnya untuk mengetahui apakah ada data yang tidak sesuai (missing)

2. Setelah tidak ada data yang missing, dilakukan penghitungan distribusi frekuensi dari masingmasing variable.

3. Sistem skoring digunakan untuk memberikan penilaian dan mengarahkan simpulan setiap sub variable dari variable perilaku menggosok gigi. System skoring pada variable perilaku menggosok gigi didapatkan berdasarkan penilaian beberapa pertanyaan tentang sub variable. Setiap jawaban benar akan diberi nilai 1 . Hasil skoring kemudian dikelompokkan menjadi perilaku menggosok gigi yang baik dan kurang baik. Cut of point dari penilaian tersebut didapat dari median total skor. Perilaku menggosok gigi yang baik adalah total skor yang lebih dari nilai median, sedangkan yang kurang baik adalah total skor yang kurang dari sama dengan median.

\section{HASIL PENELITIAN}

Distribusi Frekuensi Karakteristik Sampel
1. Distribusi Frekuensi Karakteristik Sampel

Tabel 5.1 menunjukkan jumlah siswa yang dijadikan sampel penelitian. Penelitian ini dilakukan di Sekolah Dasar yang terdapat di wilayah kerja Puskesmas Rendang, Karangasem. Sampel yang diambil berjumlah 39 orang yaitu siswa kelas 1 di SDN 2 dan SDN 4 Rendang yang menderita karies.

Dari seluruh sampel, terlihat lebih dari setengah sampel adalah laki-laki (69\%) dan sisanya adalah perempuan. Dilihat dari rentang umur, sampel dengan umur 6 tahun lebih banyak persentasenya yaitu $56 \%$ dibandingkan dengan sampel yang berumur 7 tahun. Karakteristik demografi pada penelitian ini tidak dicantumkan oleh karena rerata letak geografis, suku bangsa, dan kultur social yang hampir sama yaitu orang Bali dan menganuut budaya dan adat istiadat sebagai orang Bali.

Tabel 5.1 Distribusi Frekuensi Karakteristik Sampel

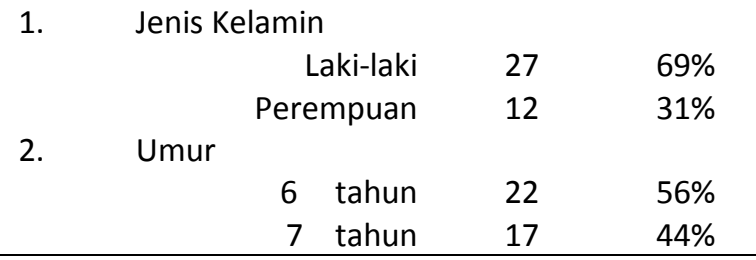

\section{Gambaran Perilaku Menggosok Gigi}

Tabel 5.2 Distribusi Frekuensi Gambaran Perilaku Menggosok Gigi

Menggosok gigi setiap hari

$\begin{array}{rrr}\text { Ya } & 27 & 69.2 \% \\ \text { Tidak } & 12 & 30.8 \%\end{array}$

Menggunakan sikat gigi sendiri

$\begin{array}{rrr}\text { Ya } & & 70.4 \% \\ \text { Tidak } & 19 & 29.6 \% \\ & 8 & \end{array}$

Menggunakan pasta gigi

$\begin{array}{rcr}\text { Ya } & 24 & 88.9 \% \\ \text { Tidak } & 3 & 11.1 \%\end{array}$

Durasi menggosok gigi

benar $4 \quad 14.8 \%$

salah $\quad 23 \quad 85.2 \%$

Jenis sikat gigi

benar $\quad 19 \quad 70.4 \%$

salah $\quad 8 \quad 29.6 \%$

Alasan tidak menggosok gigi

setiap hari

Malas $\quad 1 \quad 8,3 \%$


untuk menggosok gigi jika dilakukan bersamaan saat mandi pagi ataupun sore hari. Sampel yang menggosok gigi setelah sarapan maupun sebelum tidur masih sangat sedikit, penyebabnya kebanyakan oleh karena rasa malas dan lupa pada beberapa sampel namun adapula yang merasa sudah menggosok gigi nya 2 kali sehari saat mandi pagi dan sore sehingga merasa tidak perlu melakukannya lagi di waktu lainnya.

Tabel 5.3 Distribusi Frekuensi Gambaran Waktu mengatakan menggunakan sikat gigi bersama dengan saudaranya dan beberapa ada yang bersama orang tua. Penggunaan pasta gigi terlihat pada $88.9 \%$ sampel yang kebanyakan menggunakan pasta gigi yang memiliki rasa buah-buahan. $11.1 \%$ sampel yang tidak menggunakan pasta gigi mengaku hanya menggosok gigi nya dengan sikat gigi saja karena malas menggunakan pasta gigi walaupun terdapat pasta gigi dirumahnya. Durasi dalam menggosok gigi yang diobservasi saat penelitian hanya sedikit yang sudah melakukannya dengan benar, rata-rata menggosok mereka hanya 1 - 1,5 menit saja. Pemilihan sikat gigi hampir setengah dari sampel sudah menggunakan sikat gigi yang sesuai, yang menggunakan sikat gigi yang masih salah dikarenakan ketidaktahuan karena hanya menerima dari orangtua saja kemudian langsung memakainya. Pada sampel yang tidak menggosok gigi nya setiap hari dominan mengatakan bahwa mereka lupa, lupa oleh karena tidak ada yang menyuruh, mengingatkan untuk menggosok gigi dan memberitahu kapan saja seharusnya menggosok gigi. Alasan yang kedua adalah tidak senang yaitu sebesar $25 \%$, alasan yang terakhir adalah malas. Dampak dari karies gigi adalah rasa nyeri atau sakit pada gigi, namun menurut tabel sampel yang pernah mengalami sakit gigi dan yang tidak, memiliki persentase yang hampir sama.

Tabel 5.3 menunjukkan sampel lebih sering menggosok gigi saat mandi pagi dan/ atau mandi sore, kurangnya pengetahuan sampel dan orang tua terhadap waktu menggosok gigi yang benar menyebabkan kebiasaan yang salah dan juga oleh karena ditemukannya kemudahan dalam mengingat 
dengan waktu menggosok gigi yang benar pada pagi hari dan malam hari, didapatkan persentase dibawah $15 \%$ untuk siswa yang sudah benar dalam waktu menggosok gigi pada pagi ataupun malam hari.

Tabel 5.5 Distribusi Frekuensi Waktu Menggosok Gigi Setiap Hari

1. Waktu menggosok gigi yang benar (pagi\&malam)

\begin{tabular}{ccc} 
Benar & 1 & $3.7 \%$ \\
Salah & 26 & $96.3 \%$ \\
\hline
\end{tabular}

Hanya 3.7\% sampel yang sudah menggosok gigi pada waktu yang benar yaitu pagi setelah sarapan dan malam sebelum tidur. Seperti yang sudah dijelaskan pada tabel sebelumnya bahwa sampel yang menggosok gigi nya 2 kali sehari hanya 21 sampel dari total 27 siswa yang menggosok gigi setiap hari. Faktor pengetahuan dan peran orang tua memang sangat berpengaruh pada kepatuhan serta frekuensi menggosok gigi yang dilakukan pada siswa SD kelas 1 di wilayah kerja Puskesmas Rendang.

Tabel 5.6 Distribusi Frekuensi Gambaran Metode

\begin{tabular}{|c|c|c|c|}
\hline \multicolumn{4}{|c|}{ Menggosok Gigi } \\
\hline No & Metode menggosok gigi & $f$ & $\%$ \\
\hline \multirow[t]{4}{*}{1.} & Gigi depan (seri dan taring) & & \\
\hline & $\begin{array}{l}\text { permukaan luar dengan } \\
\text { gerakan naik turun }\end{array}$ & & \\
\hline & Benar & 18 & $66.7 \%$ \\
\hline & Salah & 9 & $33.3 \%$ \\
\hline \multirow[t]{4}{*}{2.} & Gigi depan (seri dan taring) & & \\
\hline & $\begin{array}{l}\text { permukaan dalam dengan } \\
\text { gerakan mengungkit }\end{array}$ & & \\
\hline & Benar & 8 & $29.6 \%$ \\
\hline & Salah & 19 & $70,4 \%$ \\
\hline \multirow[t]{4}{*}{3.} & Gigi belakang (geraham) & & \\
\hline & $\begin{array}{l}\text { permukaan luar dengan } \\
\text { gerakan memutar }\end{array}$ & & \\
\hline & Benar & 10 & $37 \%$ \\
\hline & Salah & 17 & $63 \%$ \\
\hline \multirow[t]{4}{*}{4.} & Gigi belakang (geraham) & & \\
\hline & $\begin{array}{l}\text { permukaan dalam dengan } \\
\text { gerakan mengungkit }\end{array}$ & & \\
\hline & Benar & 3 & $11.1 \%$ \\
\hline & Salah & 24 & $88.9 \%$ \\
\hline \multirow[t]{2}{*}{5.} & Gigi belakang (geraham) & & \\
\hline & permukaan atas dengan & & \\
\hline
\end{tabular}

\begin{tabular}{cccr}
\hline gerakan maju mundur & 26 & $96.3 \%$ \\
& Benar & 1 & $3.7 \%$ \\
Salah & & \\
\hline
\end{tabular}

Dilihat dari metode menggosok gigi, sebagian besar sampel sudah dapat menggosok gigi belakang (geraham) permukaan atas dengan gerakan maju mundur dan gigi depan (seri dan taring) permukaan luar dengan gerakan naik turun dengan benar. Menggosok gigi belakang (geraham) permukaan dalam dengan gerakan mengungkit masih sedikit dilakukan oleh sampel, banyak yang melupakan untuk menggosok gigi bagian tersebut dan melewatkannya ke gigi bagian lain, ada pula yang menggosok gigi dengan gerakan yang salah. Menggosok gigi depan (seri dan taring) permukaan dalam dengan gerakan mengungkit hanya dilakukan benar oleh 30,8\% siswa dan 20,5\% menggosok gigi belakang (geraham) permukaan luar dengan gerakan memutar.

\section{Distribusi Frekuensi Gambaran Perilaku Menggosok Gigi Menurut Sistem Skoring}

Tabel 5.8 Distribusi Frekuensi Skor Gambaran Perilaku Menggosok Gigi Sistem Skoring

\begin{tabular}{lcc}
\hline Perilaku Menggosok Gigi & f & $\%$ \\
\hline Baik (skor $>4$ ) & 5 & $18.5 \%$ \\
Kurang Baik $(\leq 4)$ & 22 & $81.5 \%$ \\
\hline
\end{tabular}

Pada sampel yang diteliti didapatkan hanya $18.5 \%$ yang sudah memiliki perilaku menggosok gigi yang baik, perilaku menggosok gigi yang baik ini didapat dari hasil cut of point yang didapatkan dari median total skoring dilihat dari rutinitas, frekuensi, durasi, penggunaan pasta gigi, waktu dan metode menggosok gigi yang baik dan benar.

\section{PEMBAHASAN}

\section{Karakteristik Sampel}

Beberapa penelitian menunjukkan tingginya angka karies gigi pada anak-anak. Penelitian yang dilakukan oleh Idarto, dkk di Desa Pertima, Karangasem tahun 2007, Prevalensi karies gigi pada anak SD kelas 1 sampai 6 tersebut adalah 82,4 \%. ${ }^{5}$ Penelitian lain yang dilakukan oleh Nunn, dkk tahun 2009 juga 
menunjukkan tingginya prevalensi karies gigi pada early childhood. Prevalensi paling tinggi ditemukan pada anak usia 5-6 tahun yaitu 76,1\%. Pada tabel dapat dilihat bahwa derajat karies gigi yang paling banyak ditemukan pada sampel adalah karies profunda, yang diikuti oleh karies gigi medial dan suferfisial. Hal tersebut menunjukkan bahwa karies gigi yang dialami anak-anak sudah sangat menghawatirkan. Tingginya angka karies gigi dapat dikarenakan rendahnya kesadaran anak maupun orang tua tentang pentingnya perawatan gigi, sehingga menyebabkan cepatnya perkembangan karies gigi menjadi derajat yang lebih parah. Para orang tua biasanya sering menganggap karies pada gigi susu kurang penting karena gigi susu yang karies dianggap akan tanggal dan digantikan dengan gigi permanen yang lebih baik. Pradigma inilah yang membuat sering kali karies gigi susu disepelekan dan kurang mendapatkan perawatan. ${ }^{6}$ Hal ini memerlukan perawatan lebih lanjut karena kondisi karies gigi anak yang sebagian besar belum tertangani agar status karies gigi anak tidak bertambah parah.

Berdasarkan jenis kelamin, anak-anak sekolah berjenis kelamin laki-laki memiliki rata-rata karies gigi lebih tinggi sebesar $69 \%$ dari pada anak berjenis kelamin perempuan sebesar 31\%. Penelitian yang dilakukan oleh Joshi pada tahun 2005 di india dari total populasi diperoleh kejadian karies pada laki-laki lebih besar dibandingkan wanita hal ini dikarenakan wanita lebih memiliki keinginan untuk menjaga kebersihannya. Menurut penelitian yang dilakukan Al-Ahsa, Arab Saudi, ditemukan angka karies lebih rendah pada anak perempuan, hal tersebut berkaitan dengan faktor kultur setempat dimana para orang tua lebih memberikan perhatian yang lebih besar terhadap higienitas dan kecantikan pada anak perempuan mereka. ${ }^{7}$ Namun banyak survai yang menemukan bahwa anak perempuan memiliki prevalensi karies yang lebih tinggi dari pada anak laki-laki pada umur kronologis yang sama. Hal tersebut terkait dengan fakta bahwa rata-rata gigi permanen pada anak perempuan lebih dahulu erupsi dari pada anak laki-laki, sehingga lebih lama terpapar serangan karies. ${ }^{8}$
Dari hasil penelitian karies gigi pada anak SD kelas I usia 6-7 tahun berdasarkan kategori umur. Jumlah karies lebih banyak pada umur 6 tahun yaitu 22 orang (56\%), dan pada umur 7 tahun yaitu 17 orang (44\%). Hasil ini menunjukkan bahwa kejadian karies pada kedua kelompok usia tersebut memiliki pengalaman karies gigi yang sama. Beberapa penelitian juga menunjukkan bahwa kejadian karies lebih banyak dialami pada anak yang usianya lebih muda, menurut penelitian Desak dkk di Pukesmas Susut, Kab Bangli, tahun 2011 bahwa siswa yang berusia 10 tahun mengalami karies gigi hamper 95\% sedangkan pada usia 11 tahun prevalensinya 32\%. ${ }^{9}$ Kejadian ini juga bisa dipengaruhi oleh beberapa faktor lain seperti kebersihan gigi dan mulut, serta pemilihan makanan yang dikonsumsi yang dapat menyebabkan terjadinya karies gigi, dimana anak yang usianya lebih tua kemungkinan memiliki tanggung jawab terhadap diri sendiri untuk menjaga kesehatan gigi yang lebih besar dan memiliki pemahaman yang lebih tinggi terhadap penyuluhan maupun informasi tentang kesehatan gigi. ${ }^{10}$

\section{Perilaku menggosok gigi}

Banyak faktor yang dapat mempengaruhi timbulnya masalah karies gigi. Dalam penelitian ini, Gambaran perilaku menggosok gigi yang diteliti meliputi, rutinitas, penggunaan sikat gigi sendiri, penggunaan pasta gigi, frekuensi menggosok gigi, durasi menggosok gigi, jenis sikat gigi yang benar.dan waktu serta cara menggosok gigi yang benar

Dari hasil penelitian yang didapat sebagian besar dari sampel menggosok gigi setiap hari. Dilihat dari frekuensi menggosok gigi didapatkan siswa yang memiliki karies gigi sebagian besar sudah menggosok gigi 2 kali sehari namun tetap memiliki karies gigi sehingga dapat disimpulkan bahwa hanya dengan menggosok gigi 2 kali sehari tidak menjadi faktor tunggal penyebab karies. Menurut penelitian yang dilakukan oleh Silvia Anitasari dkk, 2005 menggosok gigi dengan frekuensi 2 kali sehari atau lebih memiliki tingkat kesehatan mulut yang lebih tinggi dari sampel yang menggosok gigi 1 kali sehari. Perbedaan karakteristik sampel seperti usia memungkinkan perbedaan hasil yang didapat. Menurut teori, asam 
plak gigi akan menurunkan $\mathrm{pH}$ normal sampai mencapai $\mathrm{pH} 5$ dalam waktu 3-5 menit sesudah makan makanan yang mengandung karbohidrat. Menggosok gigi dapat mempercepat proses kenaikan $\mathrm{pH}$ menjadi normal ( $\mathrm{pH}$ 6-7) sehingga dapat mencegah proses pembentukan karies. ${ }^{11}$

Sebanyak $67 \%$ dari sampel menggunakan pasta gigi sewaktu menggosok gigi. Ini menunjukkan bahwa penggunaan pasta gigi saat menggosok gigi masih dapat menimbulkan karies gigi. Sebuah penelitian yang dilakukan Norman Tinanoff, 2002 menyatakan bahwa penggunaan pasta gigi dapat menurunkan kejadian karies pada anak yang berumur 3-6 tahun. ${ }^{12}$ Penelitian tersebut dilakukan secara observasional dimana responden ada yang diberi instruksi untuk berkumur hanya 1 kali dan ada yang tidak, sehingga terdapat perbedaan hasil dengan penelitian yang kami lakukan. Fungsi utama pasta gigi adalah membantu sikat gigi membersihkan permukaan gigi dan sisi-sisa makanan. Fungsi sekundernya untuk memperkilat gigi, meningkatkan kesehatan gingival serta untuk mengurangi bau mulut sekali gus menurunkan kejadian karies pada gigi. ${ }^{13}$

Pada penelitian ini siswa yang sudah menggosok gigi dengan frekuensi 2 kali sehari sudah melebihi 50\% namun dilihat dari waktu saat menggosok gigi, hanya $3,7 \%$ yang sudah melakukannya dengan benar pagi setelah sarapan dan malam sebelum tidur. Jika dilihat secara terpisah, siswa yang menggosok gigi dengan benar saat pagi hari atau malam hari juga masih dibawah 15\%. Ini menandakan masih sedikitnya kedisiplinan terhadap waktu atau kurangnya pengetahuan siswa maupun orang tua. Menurut suatu penelitian didapatkan bahwa menggosok gigi setelah sarapan dan sebelum tidur ada kecenderungan semakin sedikit yang memiliki karies. ${ }^{14}$

Cara menggosok gigi merupakan satu lagi faktor yang memainkan peranan penting dalam menentukan timbulnya karies gigi terlihat dari tidak adanya siswa yang berperilaku cara menggosok gigi yang baik. Namun dilihat secara terpisah, beberapa siswa sudah menggosok gigi dengan cara yang benar pada bagian gigi depan (seri dan taring) permukaan luar dengan gerakan naik turun dan gigi belakang (geraham) permukaan atas dengan gerakan maju mundur. Gigi depan (seri dan taring) permukaan dalam dengan gerakan mengungkit, gigi belakang (geraham) permukaan luar dengan gerakan memutar, gigi belakang (geraham) permukaan dalam dengan gerakan mengungkit masih tidak benar dilakukan oleh lebih dari 70\% siswa SD kelas 1 di wilayah kerja Puskesmas Rendang. Menurut teori, menggosok gigi dengan pergerakan yang benar menyebabkan plak dibersihkan secara lebih efektif dan menghalang dari terjadinya karies pada gigi (Joanna Asadoorian, 2006). Hampir semua sampel gagal dalam mempraktekkan cara menggosok gigi yang baik dan perilaku ini secara langsung menjadi faktor yang memicu kepada kejadian karies gigi pada sampel.

Durasi menggosok gigi sebagian besar dari sampel adalah kurang dari durasi yang dianjurkan yaitu 2 menit. Hanya sebagian kecil dari sampel yang menggosok gigi selama 2-3 menit yaitu sebanyak $12,9 \%$. Walaupun frekuensi dan cara menggosok gigi sudah baik tapi jika durasi menggosok gigi tidak sesuai, ini akan menyebabkan karies gigi tetap terjadi karena durasi itu penting untuk memastikan gigi benar-benar bersih. Menurut teori, durasi menggosok gigi yang benar adalah selama 2-3 menit. ${ }^{15}$

Sebahagian besar sampel menggunakan jenis sikat gigi yang benar dan yaitu sebanyak 69,2\%, Siswa yang tidak menggunakan sikat gigi yang benar mengatakan tidak mempunyai sikat gigi sendiri. Jenis sikat gigi yang benar akan menyebabkan plak dapat dibersihkan sampai ke celah-celah gigi dan menurunkan angka timbulnya karies. ${ }^{13}$

Sikat gigi yang dianjurkan adalah sikat gigi yang lembut karena sikat gigi yang keras dapat merusak lapisan enamel dan melukai gigi. Hal tersebut dapat mengundang karies ataupun menjadikan karies yang ada untuk menjadi lebih parah. Untuk bisa menjangkau daerah-daerah gigi di bagian belakang, ukuran kepala sikat yang ideal adalah 35-40 mm.

\section{Kelemahan Penelitian}

Kelemahan Penelitian ini adalah : 
1. Pemberian informasi pada saat wawancara terlalu umum sehingga sampel menjawab wawancara berdasarkan apa yang diajarkan oleh orang tua, guru, dan informasi media bukan berdasarkan apa yang mereka lakukan di rumah.

2. Pemilihan sampel diambil dari SDN yang mudah dicapai oleh peneliti oleh karena keterbatasan waktu yang dimiliki.

3. Tidak terdapat cadangan sampel pada penelitian ini.

\section{SIMPULAN DAN SARAN}

\section{Simpulan}

1. Gambaran perilaku menggosok gigi yang baik pada siswa Sekolah Dasar di wilayah kerja Puskesmas Rendang masih sangat kurang, hanya $18.5 \%$ yang sudah berperilaku menggosok gigi dengan baik dan sisanya masih dalam kategori kurang baik

2. Frekuensi menggosok gigi pada siswa Sekolah Dasar di wilayah kerja Puskesmas Rendang sebagian besar sudah melakukan 2 kali sehari namun masih banyak siswa yang tidak melakukannya pada waktu dan cara yang benar

3. Metode menggosok gigi pada siswa Sekolah Dasar di wilayah kerja Puskesmas Rendang sebagian besar masih salah dalam segi arah, gerakan saat menggosok gigi. Siswa banyak yang melewatkan untuk menggosok gigi belakang (geraham) permukaan dalam dengan gerakan mengungkit, Gigi belakang (geraham) permukaan luar dengan gerakan memutar, Gigi depan (seri dan taring) permukaan dalam dengan gerakan mengungkit.

4. $3.7 \%$ siswa Sekolah Dasar di wilayah kerja Puskesmas Rendang menggosok gigi pada waktu yang benar dan sisanya masih menggosok gigi pada waktu yang salah.

\section{Saran}

1. Dilihat dari kejadian karies gigi yang masih tinggi diwilayah kerja Puskesmas Rendang diharapakan petugas puskesmas terkait memberikan perhatian lebih terhadap kesehatan gigi anak-anak SD kelas 1 diwilayah kerjanya, misalnya dengan mengadakan penyuluhan kesehatan gigi yang lebih menekankan pada perubahan perilaku menggosok gigi kearah yang lebih baik yang meliputi gerakan sikat gigi yang benar, bagian gigi yang harus digosok saat menggosok gigi, waktu menggosok gigi yang tepat dan pengetahuan mengenai makanan yang dapat menimbulkan karies gigi.

2. Upaya peningkatan kesehatan gigi pada anak-anak tidak hanya dilakukan oleh petugas kesehatan terkait, tetapi oleh anak itu sendiri serta orang tua mereka masing-masing. Pengetahuan dan perilaku orang tua dalam hal ini perlu ditingkatkan, begitu pula peran pemerintah dikawasan tersebut untuk menunjang program kesehatan gigi dan mulut bersama-sama dengan pukesmas.

3. Perlu dikembangkan suatu upaya untuk meningkatkan perilaku anak dalam menjaga kesehatan gigi dan mulut. Salah satu upaya yang dapat dilakukan dengan menanamkan kebiasaan menggosok gigi disekolah. Serta pihak sekolah juga perlu memotivasi siswanya yang menderita karies gigi untuk ke dokter gigi agar status kariesnya tidak bertambah parah.

4. Melatih tenaga non-dental untuk menjadi agen promotif/preventif kesehatan gigi di sekolah seperti guru UKS dan dokter kecil.

\section{DAFTAR PUSTAKA}

1. Anitasari S, Rahayu N E. 2005. The relation of frequency of teeth brush with oral hygiene of state elementary school children in Palaran area district of Samarinda province of east Kalimantan :Maj. Ked. Gigi. (Dent. J.), Vol 38, ; 88-90

2. Angela A. 2005. Primary prevention in children with high caries risk. Fakultas Kedokteran Gigi Universitas Sumatera Utara : Maj. Ked. Gigi. (Dent. J.), Vol 38, No 3; 130 - 134

3. Badan Penelitian dan Pengembangan Kesehatan. 2007. Laporan Riskesdas 2007 Provinsi Bali: Jakarta

4. Sheiham A. 2005. Oral Health, General Health and Quality Of Life. Bulletin Of The World Health Organization

5. Idarto A, Sumiari L. 2006. Gambaran Kejadian Karies Gigi dan Faktor-faktor Prilaku Pada Siswasiswi SDN 1 Pertima Karangasem. Denpasar : FK Unud 
6. Warni L. 2009. Hubungan Prilaku Murid Kelas 5 dan 6 Pada Kesehatan Gigi dan Mulut Terhapap Status Karies Gigi di Wilayah Deli tua Kabupaten Deli Serdang. Jakarta

7. Al-malik, dkk. 2006. Prevalence of Dental caries, severity and Pattern in Age 6 to 7 Year old Children in A Selected Community In Saudi Arabia. J Contemp Dent Pract ;(7)2:046054.

8. Riyanti E. 2005. Pengenalan dan Perawatan Gigi Anak Sejak Dini dalam Seminar Sehari Kesehatan Psikologi Anak. Jakarta

9. Desak W, Suga M. 2011. Prevalensi Karies Gigi dan Gambaran Kesulitan Akibat Karies Gigi pada Siswa Sekolah Dasar Wilayah Kerja Pukesmas Susut Kabupaten Bangli. FK Unud

10. Riyanti E. 2005. Pengenalan dan Perawatan Gigi Anak Sejak Dini dalam Seminar Sehari Kesehatan Psikologi Anak. Jakarta

11. Agim Begzati, dkk. 2010. Early childhood caries in preschool children of Kosovo. BMC Public Health

12. Norman T,dkk. 2002. Current understanding of the epidemiology, mechanisms, and prevention of dental caries in preschool childrens. 24:6:543551

13. Harold L. 2000. Oral hygiene in the prevention of caries and periodontal disease. International Dental Journal. Volume 50, issue 3, 129-139

14. Made A, Oktarina, Muhammad A M. 2010. Hubungan pola makan dan kebiasaan menyikat gigi dengan kesehatan gigi dan mulut (Karies) di Indonesia. Bulletin penelitian system kesehatan ;13:1:83-91

15. Joanna Asadoorian. 2006. Tooth brushing. Canadian journal of dental hygiene. ;40:1-14

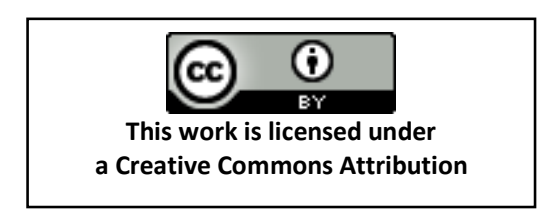

